\title{
Impact of organic amendments on soil carbon sequestration, water use efficiency and yield of irrigated wheat
}

\author{
Samreen Shehzadi ${ }^{(1,2)}$, Zahir Shah ${ }^{(2)}$, Wisal Mohammad ${ }^{(3)}$ \\ (1) Pakistan Institute of Nuclear Science and Technology (PINSTECH). P.O. Nilore. Islamabad (Pakistan). E-mail: \\ sshehzadi11@hotmail.com \\ (2) The University of Agriculture. Department of Soil and Environmental Sciences. Peshawar, 25000 (Pakistan). \\ ${ }^{(3)}$ Nuclear Institute for Food and Agriculture (NIFA). P.O. Box. No.446. Tarnab, Peshawar (Pakistan).
}

Received on December 12, 2015; accepted on October 18, 2016.

This article is distributed under the terms and conditions of the CC-BY License (http://creativecommons.org/licenses/by/4.0)

Description of the subject. Soil organic carbon (SOC) plays critical role in terrestrial carbon (C) cycling and is central to preserving soil quality, food security and environmental protection in agroecosystem. The prevailing soil and climatic conditions of cultivated and irrigated soils in warm semi-arid areas favor the rapid decomposition, mineralization and loss of SOC to the atmosphere which contribute to global warming. One potential strategy to address this $\mathrm{C}$ loss is the addition of organic amendments.

Objectives. To investigate the effect of four contrasting organic wastes with and without NPK mineral fertilizer on SOC retention, water use efficiency (WUE) and wheat yield in irrigated wheat-maize cropping system.

Method. A 2-year field experiment was conducted using four organic wastes included municipal solid waste (MSW), farm yard manure (FYM), sugar industry waste (filter cake) and maize cropping residues. All wastes were applied at $3 \mathrm{t} \mathrm{C} \cdot \mathrm{ha}^{-1}$ alone and with a full or half dose of NPK mineral fertilizer.

Results. On average, among organic wastes as sole treatment, highest SOC content in the $0-15 \mathrm{~cm}$ layer was recorded in filter cake $\left(6.5 \mathrm{t} \cdot \mathrm{ha}^{-1}\right)$ and MSW $\left(5.9 \mathrm{t} \cdot \mathrm{ha}^{-1}\right)$. Addition of NPK fertilizer along with organic wastes, improved the SOC contents with the highest SOC $\left(7.7 \mathrm{t} \cdot \mathrm{ha}^{-1}\right)$ by filter cake + full NPK treatment followed by the MSW + NPK $\left(6.9 \mathrm{t} \cdot \mathrm{ha}^{-1}\right)$. On average, maximum wheat grain WUE $\left(18 \mathrm{~kg} \cdot \mathrm{ha}^{-1} \cdot \mathrm{mm}^{-1}\right)$ and grain yield $\left(4.8 \mathrm{t} \cdot \mathrm{ha}^{-1}\right)$ were obtained by MSW + full NPK treatment followed by filter cake + NPK.

Conclusions. These results indicate that the targeted addition of organic wastes (filter cake or MSW) have the best potential for improving SOC retention, WUE and wheat yield in irrigated maize-wheat cropping system.

Keywords. Triticum aestivum, organic wastes, soil organic carbon, semiarid zones, irrigated soils.

Impact des amendements organiques sur la séquestration du carbone du sol, l'efficacité d'utilisation de l'eau et le rendement du blé irrigué

Description du sujet. Le carbone organique du sol (COS) joue un rôle critique dans le cycle du carbone et intervient de manière capitale dans la préservation des sols, la sécurité alimentaire et la protection environnementale des agro-écosystèmes. La nature du sol et les conditions climatiques des sols cultivés et irrigués dans des régions chaudes semi-arides favorisent la décomposition rapide, la minéralisation et le transfert du COS vers l'atmosphère. Cela contribue au réchauffement climatique. Une stratégie permettant d'éviter cette perte est l'ajout d'amendements organiques au sol.

Objectifs. Investiguer l'effet de quatre sources de déchets organiques épandus (avec ou sans adjonction de fertilisants minéraux de type NPK) sur la rétention du COS, l'efficience de l'eau (EUE), les rendements en blé dans un système de culture mixte froment-maïs irrigué.

Méthode. Une experimentation de deux années utilisant quatre types de déchets organiques (déchets municipaux solides [MSW], fumier [FYM], résidu solide de filtration d'industrie sucrière et résidus de culture de maïs) a été conduite. Tous les amendements organiques ont été appliqués à raison de $3 \mathrm{tC} \cdot \mathrm{ha}^{-1}$, soit seuls soit avec une dose ou une demi-dose de fertilisant minéral de type NPK.

Résultats. En moyenne, parmi les divers traitements à l'aide de déchets organiques, le plus important COS dans les 15 premiers $\mathrm{cm}$ de sol a été constaté pour les ajouts de résidu solide de filtration d'industrie sucrière $\left(6,5 \mathrm{t} \cdot \mathrm{ha}^{-1}\right)$ et MSW $(5,9 \mathrm{t}$. $\mathrm{ha}^{-1}$ ). L'addition de fertilisant NPK en plus des amendements organiques améliore le COS. Des valeurs de 7,7 t SOC.ha-1 et de 
6,9 t SOC $\cdot \mathrm{ha}^{-1}$ ont été observées pour l'ajout de résidu solide de filtration d'industrie sucrière et pour MSW $+\mathrm{NPK}$, respectivement. En moyenne, les EUE $\left(18 \mathrm{~kg} \cdot \mathrm{ha}^{-1} \cdot \mathrm{mm}^{-1}\right)$ et les rendements en grain maxima $\left(4,8 \mathrm{t} \cdot \mathrm{ha} \mathrm{a}^{-1}\right)$ ont été observés pour le traitement MSW + NPK (dose unitaire) suivis par le traitement de résidu solide de filtration d'industrie sucrière + NPK.

Conclusions. Les résultats indiquent que l'addition de résidu solide de filtration d'industrie sucrière et MSW conduisent à une rétention améliorée du COS, du EUE et du rendement en grains dans un système cultural mixte irrigué de type maïs-froment. Mots-clés. Triticum aestivum, déchet organique, carbone organique du sol, zone semi-aride, sol irrigué.

\section{INTRODUCTION}

Rapid decomposition of soil organic matter (SOM) in irrigated, warm semi-arid agroecosystems can cause a major loss of nutrient capital and induces a range of adverse soil physical and chemical conditions. Combined, this loss of SOM represents an important factor responsible for low crop yields, soil fertility decline and environmental degradation (Rashid, 1994). Soil organic matter mineralization is highly dependent on the prevailing climate and soil management regime (e.g. irrigation, tillage, cropping cycle, lime and fertilizer addition) as well as socioeconomic conditions. The soil and environmental conditions of cultivated soils in semi-arid regions of the world such as Pakistan are favourable for rapid decomposition of $\mathrm{SOM}$ resulting in high rates of $\mathrm{C}$ loss to the atmosphere, contributing to global warming.

Wheat is an important staple food crop of Pakistan being grown on 8.9 million ha with an average yield of $2.83 \mathrm{tha}^{-1}$ (MINFAL, 2012). Due to the continuous cereal-based cropping system, the imbalanced use and poor availability of chemical fertilizers (Shah et al., 2003) and the intensive cultivation practices, the productivity and fertility of soils in wheat cropping areas is declining rapidly (Mohammad et al., 2008). It is reported that the cultivated soils of Pakistan are deficient in organic matter and a range of essential plant nutrients (Rashid, 1994). The non-conventional fertilizer and irrigation application practices adopted by farmers also result in the loss of essential nutrients and low water use efficiency (Iqbal et al., 1995).

The agriculture sector consumes $75-80 \%$ of water resources worldwide. Likely, the increasing competition for water by other sectors, variation in rainfall patterns and global warming due to climate changes are major challenges for crop production. One of the most important ways for reducing pressure on water resources is to improve its use efficiency for enhancing crop production. For improvement in soil fertility and water use efficiency, it is important to enhance and sustain SOM levels. Soil organic carbon (SOC) levels directly affect many soil physical, chemical and biological properties and its loss due to microbial activity is directly responsible for causing soil degradation and declining soil quality (Lal, 2004; Lal, 2006).
Sequestration of SOC is considered as an important strategy to increase SOM reserves and for mitigating the potential greenhouse effect (Lal, 2004). The increase in SOC content also has beneficial effects in enhancing soil quality, reducing soil erosion, improving water quality and increasing crop growth and agronomic productivity. It also promotes environmental quality by adsorbing pollutants from water and reducing $\mathrm{CO}_{2}$ concentrations in the atmosphere (Lal \& Kimble, 1999).

Application of different organic materials like manures, plant residues and waste materials represents an effective management strategy to improve biological and chemical properties of soils (Goyal et al., 1999). It helps to mitigate climate change by transferring the atmospheric $\mathrm{CO}_{2}$ into a more stable SOC pool. In addition, a judicious and combined use of organic and inorganic sources of nutrients is essential to maintain soil health and crop productivity. In light of this, the present study was undertaken to assess the effect of four contrasting organic solid wastes (Municipal solid waste [MSW], farm yard manure [FYM], sugar industry waste [filter cake], maize crop residues) in the absence or presence of NPK mineral fertilizers on wheat crop yield, water use efficiency and soil organic $\mathrm{C}$ under an irrigated condition.

\section{MATERIALS AND METHODS}

\subsection{Experimental site}

A two year field plot experiment (2010-2012) was performed at the Research Farm of the Nuclear Institute for Food and Agriculture (NIFA), situated at Tarnab (longitude $71^{\circ} 50 \mathrm{E}$, latitude $34^{\circ} 01 \mathrm{~N}$ ), Peshawar, Khyber Pakhtunkhwa, Pakistan. The field site is located at an altitude of $400 \mathrm{~m}$ above sea level and has cool climate in winter and warm to hot climate in the summer. Before commencement of the experiment, composite soil samples were taken from the experimental site for its characterization. These soil samples were air dried, ground, passed through a sieve $(2 \mathrm{~mm})$ and analyzed for important soil characteristics such as soil texture, $\mathrm{pH}, \mathrm{EC}_{\mathrm{e}}$, total $\mathrm{N}$, mineral $\mathrm{N}$, available $\mathrm{P}, \mathrm{K}$, bulk density and organic matter (Table 1). Soil of the experimental site was clay 
Table 1. Physico-chemical properties of experimental soil $(0-15 \mathrm{~cm})-$ Propriétés physico-chimiques du sol en expérimentation $(0-15 \mathrm{~cm})$.

\begin{tabular}{ll}
\hline Property & Value \\
\hline Sand & $21 \%$ \\
Silt & $43 \%$ \\
Clay & $36 \%$ \\
Textural class & Clay loam \\
$\mathrm{pH}(1: 2.5)$ & 7.8 \\
$\mathrm{EC}_{\mathrm{e}}(1: 2.5)$ & $0.36 \mathrm{dSm}-1$ \\
\hline Organic matter & $1.2 \%$ \\
\hline Bulk density & $1.24 \mathrm{~g} \cdot \mathrm{cm}^{-3}$ \\
\hline Total organic carbon & $0.70 \%$ \\
\hline Total nitrogen & $0.07 \%$ \\
\hline Total mineral nitrogen & $42.0 \mathrm{mg} \cdot \mathrm{kg}^{-1}$ \\
\hline Available phosphorus & $11.0 \mathrm{mg} \cdot \mathrm{kg}^{-1}$ \\
\hline Available potassium & $80.0 \mathrm{mg} \cdot \mathrm{kg}^{-1}$ \\
\hline Available $\mathrm{Zn}$ & $0.55 \mathrm{mg} \cdot \mathrm{kg}^{-1}$ \\
\hline Available Fe & $7.72 \mathrm{mg} \cdot \mathrm{kg}^{-1}$ \\
\hline Lime $\left(\mathrm{CaCO}_{3}\right)$ & $19 \%$ \\
\hline
\end{tabular}

loam (Order: Inceptisols, Sub order: Ustepts, Soil great group: Haplustepts, Soil Sub group: Udic Haplustepts, Family: Fine, mixed, hyperthermic, Udic Haplustepts, Taru Soil Series [US Soil Taxonomy]), non saline and alkaline in reaction.

\subsection{Organic wastes collection}

Farm yard manure (FYM) (well rotted, from cattle source) was collected from local farmers. Municipal solid waste (MSW) was collected from a municipal dumping ground (Ring Road, Peshawar, Pakistan). The non-decomposable materials like plastic, glass, stone and other unwanted materials were removed prior to use. Filter cake (sugar industrial processing waste) was collected from Khazana Sugar Mill, Peshawar. In the process of cane sugar preparation, the precipitated impurities are removed by filtration to form a cake with $50 \%$ moisture content. All organic wastes, after collection, were spread on a plastic sheet under the shade for drying. After air drying, a representative sample was taken and transferred to the laboratory. After drying in an oven at $70^{\circ} \mathrm{C}$ for $24 \mathrm{~h}$, all waste samples were ground to a powder in a Wiley Mill and analyzed for total C (Heanes, 1984), N (Bremner \& Mulvaney, 1982) and P (Soltonpour \& Schwab, 1977). The results showed that the total C contents were $46 \%$, $11 \%, 7 \%$ and $26 \%$ for maize residues, FYM, MSW and filter cake respectively (Table 2). Highest N (3.40\%) and $\mathrm{P}$ contents $(1.12 \%)$ were recorded in the filter cake. The C:N ratio of organic wastes ranged from 8 in the filter cake to 59 in the maize residues.

\subsection{Experimental design}

The experiment was laid out in a Randomized Complete Block Design (RCBD) with three replications. The land was prepared by applying $0-20 \mathrm{~cm}$ deep cultivator plough at sowing time following by planking. After air drying and analyses, organic waste materials were applied to designated treatment plots in both seasons. Crop residues were cut into small pieces $(6-8 \mathrm{~mm})$ before application. The waste materials were well mixed and inverted into the soil before sowing. The treatment plot size was $3 \times 5 \mathrm{~m}^{2}$. The 15 treatments included:

- Control,

- PK only (recommended dose),

- Farm Yard Manure (FYM),

- Maize residues (MR),

- Municipal Solid Waste (MSW),

- Filter cake (Sugar Industrial waste) (FC),

- NPK (recommended dose),

$-\mathrm{FYM}+1 / 2 \mathrm{NPK}$,

- Maize residues $+1 / 2$ NPK,

$-\mathrm{MSW}+1 / 2 \mathrm{NPK}$,

- Filter cake $+1 / 2$ NPK,

$-\mathrm{FYM}+$ full NPK,

- Maize residues + full NPK,

- MSW + full NPK,

- Filter cake + full NPK.

All organic wastes were applied at a rate of $3 \mathrm{tC}$. ha $^{-1}$ (Muhammad et al., 2011). Recommended NPK

Table 2. Chemical analysis of organic wastes used in the study - Analyse chimique des déchets organiques utilisés dans cette étude.

\begin{tabular}{llllll}
\hline Organic waste & Total C $(\%)$ & Total N $(\%)$ & C:N ratio & Total P $(\%)$ & Total K $(\%)$ \\
\hline Maize residues & 46 & 0.78 & 59 & 0.10 & 1.50 \\
Farmyard manure & 11 & 0.50 & 22 & 0.37 & 1.20 \\
Municipal solid waste & 7 & 0.72 & 10 & 0.25 & 1.25 \\
Filter cake & 26 & 3.40 & 8 & 1.12 & 1.30 \\
\hline
\end{tabular}


$\left(\mathrm{N}, \mathrm{P}_{2} \mathrm{O}_{5}, \mathrm{~K}_{2} \mathrm{O}\right)$ were applied as full $(120: 90: 60) \mathrm{kg}$. ha $^{-1}$ and half doses (60:45:30) kg h.ha ${ }^{-1}$.

Half doses of $\mathrm{N}$ and full doses of $\mathrm{P}$ and $\mathrm{K}$ were applied to wheat at sowing, while the remaining half of $\mathrm{N}$ was applied with the $2^{\text {nd }}$ irrigation. The sources for NPK were urea, TSP and SOP respectively. The same treatments were applied to wheat in Year 2 (2011-2012). All standard agronomic practices were carried out during the experiment. The test crop was wheat (Triticum aestivum L. cv. 'Bathoor'). Meteorological data (rainfall, temperature, humidity) during 2010-2012 were collected from adjacent Agriculture Research Institute, Tarnab, Peshawar.

The crop was harvested at its physiological maturity and data on straw and grain yields were recorded.

\subsection{Soil analyses}

After wheat harvest, soil samples $(0-15 \mathrm{~cm})$ were collected from each treatment plot and analyzed for total organic $\mathrm{C}$ according to Black (1965).

\subsection{Measurement of water use efficiency}

To study the effect of treatments on soil water storage, neutron access tubes were inserted down to $90 \mathrm{~cm}$ depth in the soil profile in each treatment plot in two replications. Before the start of experiment, neutron probe readings were calibrated with gravimetric moisture contents in soil profile in $30 \mathrm{~cm}$ increments. A known amount of irrigation water was applied to each treatment plot throughout the experiment. Neutron probe readings at regular interval at $30 \mathrm{~cm}$ increments within the soil profile were recorded from sowing through to crop harvest. The probe readings were converted to volumetric moisture contents using the bulk density of soil cores taken from each depth increment. Neutron probe readings along with meteorological observations (rainfall and temperature) were recorded regularly. The crop water use (evapotranspiration) was calculated from rainfall received and change in soil water storage to $90 \mathrm{~cm}$ depth, assuming no or negligible losses as runoff and drainage below the root zone. The water use efficiency was calculated according to water balance approach (Kirda, 1990).

\subsection{Statistical analyses}

The data were analyzed statistically according to the design through analyses of variance. The treatment means for various crop parameters were compared by LSD test using computer software Statistix 8 . Contrast analyses were also performed among eight different groups.

\section{RESULTS}

\subsection{Straw yield}

Wheat straw yields during 2010-2012 as affected by various organic wastes alone and in combination with inorganic NPK fertilizer are presented in table 3. The data show significant differences among treatments in both years. During 2010-2011 (Year 1), MSW with full NPK dose resulted in the highest straw yield (13.0 t. $\mathrm{ha}^{-1}$ ) followed by $12.5 \mathrm{t} \cdot \mathrm{ha}^{-1}$ for the filter cake treatment. Overall, during 2011-2012 (Year 2), the straw yield was higher than in the 2010-2011 season (Year 1). The highest straw yield $\left(14.3 \mathrm{t} \cdot \mathrm{ha}^{-1}\right)$ was recorded in the MSW + full NPK treatment. Among the organic wastes, maize residues used as a sole treatment had the least effect on wheat straw yield. However, with half and full NPK, it increased the average straw yield by $10.5 \%$ and $14.7 \%$ respectively. The average data further revealed that all added organic wastes alone (except maize residues) and mineral NPK fertilizer produced a statistically similar wheat straw yield. This finding may be due to the adequate supply of plant nutrients from these organic waste materials (Hussain, 2001), as most of the cultivated soils in Pakistan are developed from calcareous alluvium and loess and are deficient in organic matter, essential macro (e.g. N, P) and micronutrients (Rashid \& Ahmad, 1994; Jilani et al., 2007; Hussain et al., 1999).

Planned mean contrast analyses of data showed that all the organic wastes alone or in combination with NPK fertilizer resulted in highly significant increases in wheat straw yield over the control treatment in both the years (Table 3). Municipal solid waste and filter cake with NPK (half + full) produced a significantly higher yield than the sole treatments in both years (Table 3 ). The Years 1 and 2 data further revealed that organic wastes + full NPK resulted in significantly higher straw yields as compared to the standard inorganic NPK fertilizer regime. Integrated effect of organic wastes plus half the NPK dose showed non-significant results in comparison to a full dose of NPK.

\subsection{Grain yield}

Grain yield of wheat showed a significant increase under the treatments where the various organic wastes were added alone (except maize straw in Year 1) or in combination with NPK as compared with the control treatment during both years (Table 4). The highest grain yield was recorded in the MSW treatment in combination with a full dose of NPK in both years.

During 2010-2011 (Year 1), the highest grain yield (4.8 $\mathrm{t}^{\mathrm{h}} \mathrm{ha}^{-1}$ ) was produced by the MSW in combination with full NPK and filter cake + NPK (full dose) treatment. The comparison of solid wastes alone and 
Table 3. Effect of organic wastes with and without NPK mineral fertilizer on wheat straw yield $\left(\mathrm{t} \cdot \mathrm{ha}^{-1}\right)$ over two growing $^{-1}$ seasons - Effet des déchets organiques avec et sans engrais minéral NPK sur le rendement de la paille de blé $\left(t \cdot h a^{-1}\right)$ durant deux saisons de croissance.

\begin{tabular}{|c|c|c|c|}
\hline Treatments & Yield in 2010-2011 & Yield in 2011-2012 & Mean of the two seasons \\
\hline Control & $7.6^{\mathrm{i}}$ & $7.3^{\mathrm{i}}$ & $7.4^{\mathrm{h}}$ \\
\hline $\mathrm{PK}$ & $9.5^{\mathrm{fg}}$ & $7.4^{\mathrm{i}}$ & $8.4^{\mathrm{g}}$ \\
\hline NPK & $10.6^{\mathrm{de}}$ & $11.6^{\mathrm{def}}$ & $11.1^{\mathrm{cd}}$ \\
\hline FYM & $10.4^{\mathrm{ef}}$ & $10.8^{\mathrm{fgh}}$ & $10.6^{\mathrm{de}}$ \\
\hline FYM+ half NPK & $10.6^{\mathrm{de}}$ & $11.4^{\mathrm{efg}}$ & $11.0^{\mathrm{cd}}$ \\
\hline FYM+ full NPK & $11.7^{\mathrm{bc}}$ & $12.3^{\text {cde }}$ & $12.0^{\mathrm{b}}$ \\
\hline Maize residues & $8.5^{\mathrm{h}}$ & $8.5^{\mathrm{i}}$ & $8.5^{\mathrm{g}}$ \\
\hline Maize residues +half NPK & $8.8^{\mathrm{gh}}$ & $10.0^{\mathrm{h}}$ & $9.4^{\mathrm{f}}$ \\
\hline Maize residues + full NPK & $9.2^{\mathrm{gh}}$ & $10.3^{\text {fgh }}$ & $9.8^{\mathrm{ef}}$ \\
\hline MSW & $10.3^{\mathrm{ef}}$ & $10.3^{\mathrm{gh}}$ & $10.3^{\text {def }}$ \\
\hline MSW+ half NPK & $10.8^{\text {cde }}$ & $12.7^{\mathrm{bcd}}$ & $11.8^{\mathrm{bc}}$ \\
\hline MSW+ full NPK & $13.0^{\mathrm{a}}$ & $14.3^{\mathrm{a}}$ & $13.6^{\mathrm{a}}$ \\
\hline Filter cake & $10.4^{\mathrm{de}}$ & $11.0^{\mathrm{fgh}}$ & $10.7^{\mathrm{d}}$ \\
\hline Filter cake + half NPK & $11.3^{\mathrm{cd}}$ & $13.0^{\mathrm{bc}}$ & $12.1^{b}$ \\
\hline Filter cake + full NPK & $12.5^{\mathrm{ab}}$ & $13.7^{\mathrm{ab}}$ & $13.1^{\mathrm{a}}$ \\
\hline \multirow[t]{2}{*}{ LSD } & 0.879 & 1.288 & 0.866 \\
\hline & 2010-2011 & 2011-2012 & Planned mean comparisons \\
\hline $\begin{array}{l}\text { Control } \\
\text { Rest }\end{array}$ & $\begin{array}{l}7.6 * * \\
10.5\end{array}$ & $\begin{array}{l}7.3 * * \\
11.2\end{array}$ & Control vs rest \\
\hline $\begin{array}{l}\text { FYM sole } \\
\text { FYM + NPK }\end{array}$ & $\begin{array}{l}10.4 * \\
11.2\end{array}$ & $\begin{array}{l}10.8^{\mathrm{ns}} \\
11.9^{4}\end{array}$ & FYM alone $v s$ FYM with NPK (half + full) \\
\hline $\begin{array}{l}\text { Maize residues sole } \\
\text { Maize residues + NPK }\end{array}$ & $\begin{array}{l}8.5^{\mathrm{ns}} \\
9.0^{-}\end{array}$ & $\begin{array}{l}8.5 * * \\
10.2\end{array}$ & MR alone vs MR with NPK (half + full) \\
\hline $\begin{array}{l}\text { MSW sole } \\
\text { MSW + NPK }\end{array}$ & $\begin{array}{l}10.3 * * \\
11.9\end{array}$ & $\begin{array}{l}10.3 * * \\
13.5\end{array}$ & MSW alone $v s$ MSW with NPK (half + full) \\
\hline $\begin{array}{l}\text { Filter cake sole } \\
\text { Filter cake + NPK }\end{array}$ & $\begin{array}{l}10.4 * * \\
11.9\end{array}$ & $\begin{array}{l}11.0 * * \\
13.4\end{array}$ & FC alone $v s$ FC with NPK (half + full) \\
\hline $\begin{array}{l}\text { Organic } \\
\text { Inorganic }\end{array}$ & $\begin{array}{l}9.9 * \\
10.6\end{array}$ & $\begin{array}{l}10.1^{* *} \\
11.6\end{array}$ & Organic $v s$ inorganic \\
\hline $\begin{array}{l}\text { Organic + full NPK } \\
\text { Inorganic }\end{array}$ & $\begin{array}{l}11.6 * * \\
10.6\end{array}$ & $\begin{array}{l}12.7 * \\
11.6\end{array}$ & Organic + full NPK vs inorganic \\
\hline $\begin{array}{l}\text { Organic + half NPK } \\
\text { Inorganic }\end{array}$ & $\begin{array}{l}10.4^{\mathrm{ns}} \\
10.6\end{array}$ & $\begin{array}{l}11.8^{\mathrm{ns}} \\
11.6\end{array}$ & Organic + half NPK $v s$ inorganic \\
\hline
\end{tabular}

FYM: Farm Yard Manure - fumier; MSW: Municipal Solid Waste - déchets municipaux solides; MR: Maize Residues — résidus de culture de maïs; FC: Filter Cake - résidu solide de filtration d'industrie sucrière; Full NPK: NPK recommended dose (120-90-60) kg. $\mathrm{ha}^{-1}$ - dose recommandée de NPK (120-90-60) $\mathrm{kg} \cdot \mathrm{ha}^{-1}$; half NPK: (60-45-30) $\mathrm{kg} \mathrm{NPK} \cdot \mathrm{ha}^{-1}$; all organic wastes were applied at $3 \mathrm{t} \mathrm{C}$. ha $^{-1}$ - tous les déchets organiques furent appliqués à $3 t C \cdot h a^{-1}$; **: significant at $P<0.01-$ significatif à $\mathrm{P}<0,01$; *: significant at $P<0.05$ - significatif à $\mathrm{P}<0,05$; ns: non-significant $(P>0.05)$ - non significatif $(\mathrm{P}>0,05)$; means sharing similar letter(s) in a column do not differ significantly at $p=0.05$ - les moyennes ayant la(les) même(s) lettre (s) dans une colonne ne diffèrent pas significativement à $\mathrm{p}=0,05$.

in combination with NPK revealed an interesting interaction. When the organic wastes were applied together with half the recommended dose of NPK there was no significant increase in grain yield as compared to when the wastes were applied on their own. However, when applied in combination with a full dose of NPK, they produced significantly higher grain yields. 
Table 4. Effect of organic wastes with and without NPK mineral fertilizer on wheat grain yield (t-ha $\left.{ }^{-1}\right)-$ Effet des déchets organiques avec et sans engrais minéral NPK sur le rendement en grain du blé $\left(t \cdot h a^{-1}\right)$.

\begin{tabular}{|c|c|c|c|}
\hline Treatments & Yield in 2010-2011 & Yield in 2011-2012 & Mean of the two seasons \\
\hline Control & $3.3^{\mathrm{e}}$ & $2.5^{\mathrm{g}}$ & $2.9^{\mathrm{j}}$ \\
\hline PK & $4.2^{\mathrm{bcd}}$ & $2.7^{\mathrm{g}}$ & $3.5^{\mathrm{i}}$ \\
\hline NPK & $4.5^{\mathrm{abc}}$ & $3.6^{\mathrm{de}}$ & $4.0^{\mathrm{defg}}$ \\
\hline FYM & $4.1^{\mathrm{cd}}$ & $3.4^{\mathrm{ef}}$ & $3.7^{\text {ghi }}$ \\
\hline FYM+ half NPK & $4.2^{\mathrm{cd}}$ & $3.6^{\mathrm{cd}}$ & $3.9^{\text {efg }}$ \\
\hline FYM+ full NPK & $4.6^{\mathrm{ab}}$ & $4.0^{\mathrm{b}}$ & $4.3^{b c}$ \\
\hline Maize residues & $3.8^{\mathrm{de}}$ & $3.2^{\mathrm{f}}$ & $3.5^{\mathrm{hi}}$ \\
\hline Maize residues + half NPK & $3.9^{\mathrm{d}}$ & $3.7^{\mathrm{cd}}$ & $3.8^{\mathrm{gh}}$ \\
\hline Maize residues + full NPK & $4.5^{\mathrm{abc}}$ & $3.8^{\mathrm{bcd}}$ & $4.1^{\mathrm{bcd}}$ \\
\hline MSW & $4.3^{\mathrm{bcd}}$ & $3.8^{\mathrm{bc}}$ & $4.1^{\text {cdef }}$ \\
\hline MSW+ half NPK & $4.4^{\mathrm{abc}}$ & $4.1^{\mathrm{b}}$ & $4.2^{\mathrm{bcd}}$ \\
\hline MSW+ full NPK & $4.8^{\mathrm{a}}$ & $4.7^{\mathrm{a}}$ & $4.8^{\mathrm{a}}$ \\
\hline Filter cake & $4.0^{\mathrm{cd}}$ & $3.6^{\mathrm{cde}}$ & $3.8^{\mathrm{fg}}$ \\
\hline Filter cake + half NPK & $4.2^{\mathrm{bcd}}$ & $3.8^{\mathrm{bcd}}$ & $4.0^{\operatorname{defg}}$ \\
\hline Filter cake + full NPK & $4.8^{\mathrm{a}}$ & $4.0^{\mathrm{b}}$ & $4.4^{\mathrm{b}}$ \\
\hline \multirow[t]{2}{*}{ LSD } & 0.472 & 0.283 & 0.292 \\
\hline & $2010-2011$ & 2011-2012 & Planned mean comparisons \\
\hline $\begin{array}{l}\text { Control } \\
\text { Rest }\end{array}$ & $\begin{array}{l}3.3 * * \\
4.3\end{array}$ & $\begin{array}{l}2.5 * * \\
3.7\end{array}$ & Control vs rest \\
\hline $\begin{array}{l}\text { FYM sole } \\
\text { FYM + NPK }\end{array}$ & $\begin{array}{l}4.1^{\mathrm{ns}} \\
4.4\end{array}$ & $\begin{array}{l}3.4 * * \\
3.8\end{array}$ & FYM alone vs FYM with NPK (half + full) \\
\hline $\begin{array}{l}\text { Maize residues sole } \\
\text { Maize residues + NPK }\end{array}$ & $\begin{array}{l}3.8^{\mathrm{ns}} \\
4.2\end{array}$ & $\begin{array}{l}3.2 * * \\
3.7\end{array}$ & MR alone $v s$ MR with NPK (half + full) \\
\hline $\begin{array}{l}\text { MSW sole } \\
\text { MSW + NPK }\end{array}$ & $\begin{array}{l}4.3^{\mathrm{ns}} \\
4.6\end{array}$ & $\begin{array}{l}3.8 * * \\
4.4\end{array}$ & MSW alone $v s$ MSW with NPK (half + full) \\
\hline $\begin{array}{l}\text { Filter cake sole } \\
\text { Filter cake + NPK }\end{array}$ & $\begin{array}{l}4.0 * \\
4.5\end{array}$ & $\begin{array}{l}3.6 * \\
3.9\end{array}$ & FC alone vs FC with NPK (half + full) \\
\hline $\begin{array}{l}\text { Organic } \\
\text { Inorganic }\end{array}$ & $\begin{array}{l}4.1 * \\
4.5\end{array}$ & $\begin{array}{l}3.5^{\mathrm{ns}} \\
3.5\end{array}$ & Organic $v s$ inorganic \\
\hline $\begin{array}{l}\text { Organic + full NPK } \\
\text { Inorganic }\end{array}$ & $\begin{array}{l}4.7 \mathrm{~ns} \\
4.5\end{array}$ & $\begin{array}{l}4.1 * * \\
3.5\end{array}$ & Organic + full NPK vs inorganic \\
\hline $\begin{array}{l}\text { Organic + half NPK } \\
\text { Inorganic }\end{array}$ & $\begin{array}{l}4.2^{\mathrm{ns}} \\
4.5\end{array}$ & $\begin{array}{l}3.8 * \\
3.5\end{array}$ & Organic + half NPK vs inorganic \\
\hline
\end{tabular}

Legend - légende: see table 3 - voir table 3.

Wheat grain yield recorded during 2011-2012 (Year 2) were generally lower as compared to that obtained in 2010-2011 (Year 1). The reasons for this may include less rainfall received and the adverse effect of lodging during 2011-2012. The data further revealed that filter cake and farmyard manure added as sole sources produced grain yield of $3.6 \mathrm{t} \cdot \mathrm{ha}^{-1}$ and $3.4 \mathrm{t}$. $\mathrm{ha}^{-1}$ respectively which was statistically similar with the sole full NPK treatment $\left(3.6 \mathrm{t} \cdot \mathrm{ha}^{-1}\right)$. The reason may be due to higher nutrient contents in filter cake and farmyard manure as compared to other manures (Hussain, 2001).

The comparison among wastes in Year 2 indicated that maize crop residues alone had the least effect producing grain yield at $3.2 \mathrm{t} \cdot \mathrm{ha}^{-1}$. However along with half and full NPK, maize residues exerted significant effect producing $15.9 \%$ and $20.3 \%$ more grain yield over residues alone. The two years average data showed that MSW in combination with a full dose of NPK produced a significantly higher grain yield (4.8 $t$. 
$\left.\mathrm{ha}^{-1}\right)$, followed by filter cake + NPK $\left(4.4 \mathrm{t} \cdot \mathrm{ha}^{-1}\right)$ and FYM + NPK $\left(4.3 \mathrm{t}^{-\mathrm{ha}^{-1}}\right)$.

Planned mean contrast analyses (Table 4) showed that all the treatments resulted in highly significant increases in wheat grain yield over the control treatment in both years. During 2010-2011 (Year 1), FYM, maize residues, MSW and their combination with half and full NPK produced higher but non-significant results over wastes alone. However, in the following year (2011-2012), it resulted in significantly higher grain yields. The contrast analysis further reflects that organic wastes + full NPK produced a highly significant improvement in grain yield over the NPK alone treatment during 2011-2012. In addition, the application of organic fertilizer along with a half dose of NPK produced a grain yield statistically similar to that of mineral full NPK treatment during 2010-2011 (Table 4). This finding indicates that expenditure on NPK fertilizer could be reduced by using organic wastes along with a half dose of NPK.

\subsection{Straw water use efficiency}

The water use efficiency (WUE) of wheat as influenced by organic wastes and NPK mineral fertilizer is summarized in table 5. The data showed that integrated use of filter cake with a full dose of NPK resulted in significantly greater straw WUE of $45.2 \mathrm{~kg} \cdot \mathrm{ha}^{-1} \cdot \mathrm{mm}^{-1}$ and $61.2 \mathrm{~kg} \cdot \mathrm{ha}^{-1} \cdot \mathrm{mm}^{-1}$ in Years 1 and 2 respectively. The data further reflected that MSW + NPK produced straw WUE statistically similar to that of filter cake + NPK in both years.

Among the different added wastes, maize straw had the least effect on straw WUE in both years. However, with addition of full NPK, it improved the straw WUE $\left(34.3 \mathrm{~kg} \cdot \mathrm{ha}^{-1} \cdot \mathrm{mm}^{-1}\right)$ non-significantly (Year 1 ) and significantly $\left(44.4 \mathrm{~kg} \cdot \mathrm{ha}^{-1} \cdot \mathrm{mm}^{-1}\right)$ in Year 2 .

The two years average results showed that filter cake and MSW along with half or full dose of NPK increased the straw WUE significantly over the treatments when the wastes were applied alone. Among wastes, FYM and filter cake had similar effect on straw WUE which was statistically equivalent to the NPK alone treatment.

Contrast analyses indicated that all the treatments produced highly significant results over the control treatment in both years. Municipal solid waste and filter cake with their NPK (half + full) combinations produced a highly significant increase as compared to treatments in which the wastes were applied alone. The data further showed that during 2010-2011 (Year 1), maize residues with NPK (half and full) improved the straw WUE $\left(33.9 \mathrm{~kg} \cdot \mathrm{ha}^{-1} \cdot \mathrm{mm}^{-1}\right)$ nonsignificantly. However during Year 2, the effect was highly significant $\left(42.8 \mathrm{~kg} \cdot \mathrm{ha}^{-1} \cdot \mathrm{mm}^{-1}\right)$ as compared to when maize residues were applied alone $\left(35.9 \mathrm{~kg} \cdot \mathrm{ha}^{-1}\right.$. $\left.\mathrm{mm}^{-1}\right)$.
When comparing organic and inorganic fertilizer responses, the results indicated that inorganic fertilizer showed a highly significant increase in WUE over the organic fertilizers. However, a combination of organic wastes with full NPK mineral fertilizer yielded highly significant straw WUE of 41.0 and $53.6 \mathrm{~kg} \cdot \mathrm{ha}^{-1} \cdot \mathrm{mm}^{-1}$ over the inorganic NPK sole treatment in both years 1 and 2 respectively. The contrast analyses further revealed that integration of organic waste along with half NPK produced effect similar to the inorganic NPK treatment in both years.

\subsection{Grain water use efficiency}

The results obtained regarding grain water use efficiency of wheat as influenced by organic solid wastes with and without NPK mineral fertilizer are presented in table 6. The data for Year 1 showed that the filter cake + NPK treatment had the highest $\left(17.3 \mathrm{~kg} \cdot \mathrm{ha}^{-1}\right.$. $\mathrm{mm}^{-1}$ ) grain WUE and that this was statistically similar to the MSW + NPK treatment $\left(16.5 \mathrm{~kg} \cdot \mathrm{ha}^{-1} \cdot \mathrm{mm}^{-1}\right)$. The integrated use of organic wastes and a full dose of NPK improved the grain WUE by $15.3 \%, 13 \%, 12.6 \%$ and $8.8 \%$ by filter cake, maize residues, MSW and FYM respectively over wastes alone in Year 1. During 2011-2012 (Year 2), FYM and filter cake alone had the great impact on grain WUE, statistically equivalent to the NPK treatment. Maize residues in combination with NPK had the greater response as compared to other organic wastes with a $12.7 \%$ and $22.3 \%$ increase in grain WUE with half and full NPK over sole residues treatment. Organic wastes with half the NPK combination (Year 2) revealed that filter cake had a $9 \%$ increase, followed by $8 \%$ by FYM in grain WUE and the least by MSW (6.8\%). Filter cake and MSW in full NPK combinations resulted in almost the same increase (19\%) in wheat grain WUE.

On average, maximum grain WUE $\left(18 \mathrm{~kg} \cdot \mathrm{ha}^{-1} \cdot \mathrm{mm}^{-1}\right)$ was recorded by the integrated use of MSW and a full dose of NPK followed by 17.3 and $16.6 \mathrm{~kg} \cdot \mathrm{ha}^{-1} \cdot \mathrm{mm}^{-1}$ by the filter cake + NPK and FYM + NPK treatments respectively. All waste addition treatments (except maize residues) produced a response statistically similar to the NPK treatment.

Mean contrast analyses showed that filter cake, FYM and maize residues in their contrast with NPK (full and half) had a non-significant impact during Year 1 but the effect became highly significant in Year 2. However, MSW in contrast with MSW + NPK (half and full dose) produced highly significant results in both years. The data further revealed that organic fertilizer + half NPK (Year 2) resulted in significantly higher grain WUE $\left(16 \mathrm{~kg} \cdot \mathrm{ha}^{-1} \cdot \mathrm{mm}^{-1}\right)$ in contrast with inorganic fertilizer $\left(14.8 \mathrm{~kg} \cdot \mathrm{ha}^{-1} \cdot \mathrm{mm}^{-1}\right)$. In contrast, the organic waste + full NPK treatment produced highly significant results in comparison to with the addition of mineral NPK. 
Table 5. Effect of organic wastes with and without NPK mineral fertilizer on wheat straw water use efficiency $\left(\mathrm{kg} \cdot \mathrm{ha}^{-1} \cdot \mathrm{mm}^{-1}\right)$ over a two year period - Effet des déchets organiques avec et sans engrais minéral NPK sur l'efficacité d'utilisation de l'eau $\left(\mathrm{kg}_{\mathrm{ha}} \cdot \mathrm{mm}^{-1}\right)$ sur la paille de blé durant deux ans.

\begin{tabular}{|c|c|c|c|}
\hline Treatments & WUE in 2010-2011 & WUE in 2011-2012 & Mean \\
\hline Control & $28.88^{\mathrm{j}}$ & $32.07^{\mathrm{j}}$ & $30.66^{\mathrm{i}}$ \\
\hline PK & $36.30^{\text {fgh }}$ & $31.13^{\mathrm{j}}$ & $33.66^{\mathrm{i}}$ \\
\hline NPK & $38.40^{\text {def }}$ & $48.20^{\text {def }}$ & $43.33^{\mathrm{def}}$ \\
\hline FYM & $37.73^{\mathrm{efg}}$ & $45.34^{\text {fgh }}$ & $41.66^{\mathrm{efg}}$ \\
\hline FYM + half NPK & $41.04^{\mathrm{bcd}}$ & $47.64^{\mathrm{efg}}$ & $44.33^{\mathrm{de}}$ \\
\hline FYM + full NPK & $41.14^{\mathrm{bcd}}$ & $51.21^{\text {cde }}$ & $46.0^{\mathrm{cd}}$ \\
\hline Maize residues & $31.58^{\mathrm{ij}}$ & $35.86^{\mathrm{ij}}$ & $33.66^{\mathrm{i}}$ \\
\hline Maize residues + half NPK & $33.40^{\mathrm{hi}}$ & $41.15^{\mathrm{hi}}$ & $37.33^{\mathrm{h}}$ \\
\hline Maize residues + full NPK & $34.30^{\mathrm{hi}}$ & $44.40^{\text {fgh }}$ & $39.33^{\mathrm{gh}}$ \\
\hline MSW & $34.87^{\mathrm{gh}}$ & $42.62^{\mathrm{gh}}$ & $38.66^{\mathrm{gh}}$ \\
\hline MSW+ half NPK & $40.03^{\text {cde }}$ & $53.22^{\mathrm{bcd}}$ & $46.66^{\mathrm{cd}}$ \\
\hline MSW+ full NPK & $43.21^{\mathrm{ab}}$ & $57.57^{\mathrm{ab}}$ & $50.33^{\mathrm{ab}}$ \\
\hline Filter cake & $34.01^{\mathrm{hi}}$ & $45.64^{\mathrm{efg}}$ & $40.00^{\mathrm{fgh}}$ \\
\hline Filter cake + half NPK & $41.87^{\mathrm{bc}}$ & $55.51^{\mathrm{bc}}$ & $48.66^{\mathrm{bc}}$ \\
\hline Filter cake + full NPK & $45.21^{\mathrm{a}}$ & $61.21^{\mathrm{a}}$ & $53.33^{\mathrm{a}}$ \\
\hline \multirow[t]{2}{*}{ LSD } & 3.11 & 5.40 & 3.33 \\
\hline & 2010-2011 & 2011-2012 & Planned mean comparisons \\
\hline $\begin{array}{l}\text { Control } \\
\text { Rest }\end{array}$ & $\begin{array}{l}28.88 * * \\
38.08\end{array}$ & $\begin{array}{l}32.07 * * \\
47.191\end{array}$ & Control vs rest \\
\hline $\begin{array}{l}\text { FYM sole } \\
\text { FYM + NPK }\end{array}$ & $\begin{array}{l}37.73 * \\
41.09\end{array}$ & $\begin{array}{l}45.35^{\mathrm{ns}} \\
49.42\end{array}$ & FYM alone vs FYM with NPK (half + full) \\
\hline $\begin{array}{l}\text { Maize residues sole } \\
\text { Maize residues + NPK }\end{array}$ & $\begin{array}{l}31.58^{\mathrm{ns}} \\
33.85\end{array}$ & $\begin{array}{l}35.90 * * \\
42.80\end{array}$ & MR alone vs MR with NPK (half + full) \\
\hline $\begin{array}{l}\text { MSW sole } \\
\text { MSW + NPK }\end{array}$ & $\begin{array}{l}34.87 * * \\
41.62\end{array}$ & $\begin{array}{l}42.62 * * \\
55.40\end{array}$ & MSW alone $v s$ MSW with NPK (half + full) \\
\hline $\begin{array}{l}\text { Filter cake sole } \\
\text { Filter cake + NPK }\end{array}$ & $\begin{array}{l}34.02 * * \\
43.54\end{array}$ & $\begin{array}{l}45.64 * * \\
58.36\end{array}$ & FC alone $v s$ FC with NPK (half + full) \\
\hline $\begin{array}{l}\text { Organic } \\
\text { Inorganic }\end{array}$ & $\begin{array}{l}34.55 * * \\
38.40\end{array}$ & $\begin{array}{l}42.37 * * \\
48.20\end{array}$ & Organic vs inorganic \\
\hline $\begin{array}{l}\text { Organic + full NPK } \\
\text { Inorganic }\end{array}$ & $\begin{array}{l}41.00 * \\
38.40\end{array}$ & $\begin{array}{l}53.60 * \\
48.20\end{array}$ & Organic + full NPK $v s$ inorganic \\
\hline $\begin{array}{l}\text { Organic + half NPK } \\
\text { Inorganic }\end{array}$ & $\begin{array}{l}39.08^{\mathrm{ns}} \\
38.40^{2}\end{array}$ & $\begin{array}{l}49.38^{\mathrm{ns}} \\
48.20\end{array}$ & Organic + half NPK $v s$ inorganic \\
\hline
\end{tabular}

Legend - légende: see table 3 - voir table 3.

\subsection{Soil total organic carbon}

Soil total organic carbon $(0-15 \mathrm{~cm})$ after the wheat harvest as affected by organic and inorganic fertilizer addition is summarized in tables 7 and $\mathbf{8}$. The results obtained (Table 7) indicate that all the sources (organic/ inorganic) had a significant effect on total soil organic carbon (SOC) content.
The data for Year 1 revealed that maximum total SOC were recorded in the filter cake treatment $\left(6.37 \mathrm{t}^{\cdot} \cdot \mathrm{ha}^{-1}\right)$ followed by the MSW treatment $(4.87 \mathrm{t}$. $\left.\mathrm{ha}^{-1}\right)$. However, FYM and maize crop residues had statistically similar impact on total SOC.

The data for Year 2 showed that the highest total SOC was recorded in the MSW treatment (6.93 t. $\left.\mathrm{ha}^{-1}\right)$ followed by the filter cake $\left(6.75 \mathrm{t} \cdot \mathrm{ha}^{-1}\right)$, while 
Table 6. Effect of organic wastes with and without NPK mineral fertilizer on wheat grain water use efficiency $\left(\mathrm{kg} \cdot \mathrm{ha}^{-1}\right.$. $\left.\mathrm{mm}^{-1}\right)$ - Effet des déchets organiques avec et sans engrais minéral NPK sur l'efficience de l'eau sur les grains de blé ( $\mathrm{kg}$. $\left.h a^{-1} \cdot m m^{-1}\right)$.

\begin{tabular}{|c|c|c|c|}
\hline Treatments & WUE in 2010-2011 & WUE in 2011-2012 & Mean \\
\hline Control & $12.83^{\mathrm{e}}$ & $11.13^{\mathrm{h}}$ & $12.0^{\mathrm{h}}$ \\
\hline PK & $16.04^{\mathrm{abc}}$ & $11.64^{\mathrm{h}}$ & $14.0^{\mathrm{g}}$ \\
\hline NPK & $16.41^{\mathrm{ab}}$ & $14.83^{\mathrm{f}}$ & $15.66^{\mathrm{def}}$ \\
\hline FYM & $15.13^{\mathrm{bcd}}$ & $14.18^{\mathrm{fg}}$ & $14.66^{\mathrm{fg}}$ \\
\hline FYM+ half NPK & $16.17^{\mathrm{abc}}$ & $15.32^{\mathrm{def}}$ & $15.33^{\mathrm{ef}}$ \\
\hline FYM+ full NPK & $16.46^{\mathrm{ab}}$ & $16.89^{\mathrm{bc}}$ & $16.66^{\mathrm{bcd}}$ \\
\hline Maize Residues & $14.17^{\mathrm{de}}$ & $13.45^{\mathrm{g}}$ & $14.00^{\mathrm{g}}$ \\
\hline Maize Residues +half NPK & $14.76^{\text {bcd }}$ & $15.16^{\mathrm{ef}}$ & $15.33^{\mathrm{ef}}$ \\
\hline Maize Residues + full NPK & $16.03^{\mathrm{abc}}$ & $16.45^{\mathrm{cd}}$ & $16.00^{\text {cde }}$ \\
\hline MSW & $14.62^{\mathrm{cd}}$ & $16.04^{\text {cde }}$ & $15.33^{\mathrm{ef}}$ \\
\hline MSW+ half NPK & $16.47^{\mathrm{ab}}$ & $17.14^{\mathrm{bc}}$ & $17.0^{\mathrm{abc}}$ \\
\hline MSW+ full NPK & $16.46^{\mathrm{ab}}$ & $19.08^{\mathrm{a}}$ & $18.0^{\mathrm{a}}$ \\
\hline Filter cake & $15.04^{\mathrm{bcd}}$ & $15.0^{\text {ef }}$ & $15.0^{\mathrm{efg}}$ \\
\hline Filter cake + half NPK & $15.58^{\mathrm{bcd}}$ & $16.36^{\mathrm{cd}}$ & $16.0^{\text {cde }}$ \\
\hline Filter cake + full NPK & $17.34^{\mathrm{a}}$ & $17.77^{\mathrm{b}}$ & $17.33^{\mathrm{ab}}$ \\
\hline \multirow[t]{2}{*}{ LSD } & 1.717 & 1.182 & 1.111 \\
\hline & 2010-2011 & 2011-2012 & Planned mean comparisons \\
\hline $\begin{array}{l}\text { Control } \\
\text { Rest }\end{array}$ & $\begin{array}{l}12.83 * * \\
15.76\end{array}$ & $\begin{array}{l}11.13 * * \\
15.66\end{array}$ & Control vs rest \\
\hline $\begin{array}{l}\text { FYM sole } \\
\text { FYM + NPK }\end{array}$ & $\begin{array}{l}15.13^{\mathrm{ns}} \\
16.32\end{array}$ & $\begin{array}{l}14.18 * * \\
16.10\end{array}$ & FYM alone vs FYM with NPK (half + full) \\
\hline $\begin{array}{l}\text { Maize residues sole } \\
\text { Maize residues + NPK }\end{array}$ & $\begin{array}{l}14.17^{\mathrm{ns}} \\
15.40\end{array}$ & $\begin{array}{l}13.45 * * \\
15.80\end{array}$ & MR alone $v s$ MR with NPK (half + full) \\
\hline $\begin{array}{l}\text { MSW sole } \\
\text { MSW + NPK }\end{array}$ & $\begin{array}{l}14.62 * * \\
16.46\end{array}$ & $\begin{array}{l}16.04 * * \\
18.11\end{array}$ & MSW alone $v s$ MSW with NPK (half + full) \\
\hline $\begin{array}{l}\text { Filter cake sole } \\
\text { Filter cake + NPK }\end{array}$ & $\begin{array}{l}15.04^{\mathrm{ns}} \\
16.46\end{array}$ & $\begin{array}{l}15.00 * * \\
17.06\end{array}$ & FC alone $v s$ FC with NPK (half + full) \\
\hline $\begin{array}{l}\text { Organic } \\
\text { Inorganic }\end{array}$ & $\begin{array}{l}14.75 * \\
16.41\end{array}$ & $\begin{array}{l}14.67^{\text {ns }} \\
14.83\end{array}$ & Organic $v s$ inorganic \\
\hline $\begin{array}{l}\text { Organic + full NPK } \\
\text { Inorganic }\end{array}$ & $\begin{array}{l}16.57^{\mathrm{ns}} \\
16.41\end{array}$ & $\begin{array}{l}17.55 * * \\
14.83\end{array}$ & Organic + full NPK vs Inorganic \\
\hline $\begin{array}{l}\text { Organic }+ \text { half NPK } \\
\text { Inorganic }\end{array}$ & $\begin{array}{l}15.74^{\mathrm{ns}} \\
16.41\end{array}$ & $\begin{array}{l}16.00 * \\
14.83\end{array}$ & Organic + half NPK $v s$ inorganic \\
\hline
\end{tabular}

Legend - légende: see table 3 - voir table 3.

the lowest $\left(2.62 \mathrm{t}^{-h^{-1}}\right)$ was observed in the NPK treatment.

The two year average data (Table 7) showed that highest total SOC was recorded in the filter cake added treatment $\left(6.56 \mathrm{t} \cdot \mathrm{ha}^{-1}\right)$. Among the different organic wastes, maize residues and FYM had almost the same impact on soil carbon retention in the top soil $(0-15 \mathrm{~cm})$.
The data further revealed that during Year 1 (Table 8) after addition of NPK fertilizer, highest soil carbon content was observed in the filter cake treatment with a total SOC content of $7.68 \mathrm{t} \cdot \mathrm{ha}^{-1}$ followed by MSW (6.75 th.ha $\mathrm{a}^{-1}$ ) and maize residues $\left(3.75 \mathrm{t} \cdot \mathrm{ha}^{-1}\right)$. During Year 2 after NPK addition, total SOC was further improved with higher but statistically similar carbon contents by filter cake and MSW. The two years 
Table 7. Total organic carbon $(0-15 \mathrm{~cm})$ as influenced by organic and inorganic sources after wheat harvest - Carbone organique total $(0-15 \mathrm{~cm})$ influencé par des sources organiques et non organiques après la récolte du blé.

\begin{tabular}{llll}
\hline \multirow{2}{*}{ Treatments } & \multicolumn{3}{c}{ Total organic carbon $\left(\mathrm{t} \cdot \mathrm{ha}^{-1}\right)^{*}$} \\
\cline { 2 - 4 } & Year 1 & Year 2 & Average \\
\hline NPK & $0.75^{\mathrm{d}}$ & $2.62^{\mathrm{b}}$ & $1.68^{\mathrm{d}}$ \\
FYM & $2.06^{\mathrm{c}}$ & $3.37^{\mathrm{b}}$ & $2.71^{\mathrm{c}}$ \\
Maize residues & $2.25^{\mathrm{c}}$ & $3.53^{\mathrm{b}}$ & $2.89^{\mathrm{c}}$ \\
MSW & $4.87^{\mathrm{b}}$ & $6.93^{\mathrm{a}}$ & $5.90^{\mathrm{b}}$ \\
Filter cake & $6.37^{\mathrm{a}}$ & $6.75 \mathrm{a}$ & $6.56^{\mathrm{a}}$ \\
\hline LSD & 0.524 & 0.979 & 0.437 \\
\hline
\end{tabular}

*: TOC (organic/inorganic fertilizer) - TOC (control) - COT (engrais organique/non organique) - COT (témoin); abbreviations - abréviations : see table 3 - voir tableau 3.

Table 8. Total organic carbon at surface soil $(0-15 \mathrm{~cm})$ from different organic sources as affected by addition of NPK after wheat harvest - Carbone organique total $(0-15 \mathrm{~cm})$ de différentes sources organiques affecté par l'addition de NPK après la récolte du blé.

\begin{tabular}{llll}
\hline \multirow{2}{*}{ Treatments } & \multicolumn{3}{c}{ Total organic carbon $\left(\mathrm{t} \cdot \mathrm{ha}^{-1}\right) *$} \\
\cline { 2 - 4 } & Year 1 & Year 2 & Average \\
\hline FYM+NPK & $3.01^{\mathrm{d}}$ & $3.56^{\mathrm{b}}$ & $3.28^{\mathrm{b}}$ \\
Maize residues + NPK & $3.75^{\mathrm{c}}$ & $4.04^{\mathrm{b}}$ & $3.89^{\mathrm{b}}$ \\
MSW + NPK & $6.75^{\mathrm{b}}$ & $7.12^{\mathrm{a}}$ & $6.94^{\mathrm{a}}$ \\
Filter cake + NPK & $7.68^{\mathrm{a}}$ & $7.87^{\mathrm{a}}$ & $7.78^{\mathrm{a}}$ \\
\hline LSD & 0.184 & 1.791 & 0.869 \\
\hline
\end{tabular}

*: TOC (organic waste $+\mathrm{NPK})$ - TOC $(\mathrm{NPK})-C O T$

(déchets organiques $+N P K)-C O T(N P K)$;

abbreviations - abréviations : see table 3 - voir tableau 3.

average data indicated that FYM and maize residues after adding NPK accumulated very similar amounts of soil carbon in the topsoil.

\section{DISCUSSION}

\subsection{Crop yield}

Among the different waste materials added to soil, MSW showed a better response in increasing wheat yield as it contains a wide range of macro- and micro-nutrients required for plant growth (Shah \& Anwar, 2003). In addition, it improves the physical, chemical and biological properties of the soil by supplying organic matter (Roca-Pérez et al., 2009).
The type of organic fertilizer, its quality and its mode of application to soil can ultimately influence its effect on soil properties and the nutrient recycling (Ahmad et al., 2007). Organic wastes such as filter cake contain several plant essential nutrients and if incorporated in soil have been shown to improve a range of soil physical and chemical properties (Mian et al., 1990).

These differences arise as various organic sources have different rates of decomposition, therefore the nutrients mineralized from different organic materials and their subsequent rate of uptake by the crop vary (Pang \& Letey, 2000). Optimum use of organic fertilizers improves the physical, chemical and biological properties of soil (Goyal et al., 1999; Bolan et al., 2004), enhances nutrient use efficiency, increases cation exchange and water storage capacity, helps sustain high crop productivity (Khoshgoftarmanesh et al., 2010) and improves the phytoavailability of micronutrients in soil and their uptake by plants (Rengel et al., 1999; Schulin et al., 2009).

The possible reasons for higher yield in MSW and filter cake may be due to their low $\mathrm{C}: \mathrm{N}$ ratios and higher intrinsic nutrient contents. In contrast, the higher $\mathrm{C}: \mathrm{N}$ ratio of the maize straw failed to produce good results. Crop yield increased have been shown to increase by $250 \%$ by long-term applications of high rates of MSW-derived compost (Diacono \& Montemurro, 2010).

Integrated use of organic wastes and chemical fertilizers has an important role in improving crop yield, soil organic $\mathrm{C}$ and available N, P and K in soil (Rautaray et al., 2003; Shah \& Ahmad, 2006). Combined use of chemical fertilizers and organic waste materials may improve the efficiency of chemical fertilizers and thus reduce their use in order to improve crop productivity as well as sustaining soil health and fertility (Abedi et al., 2010). Organic solid wastes integrated with NPK fertilizer produced greater yield and the effect was higher in the case of MSW and filter cake. The integration of organic sources and chemical sources of nutrients not only supply essential nutrients but also has some positive interactions to increase efficiency (Ahmad et al., 1996). These results are in line with Gitari \& Friesen (2001) who reported that the use of combined organic and inorganic soil amendments was superior to either an organic or inorganic source alone. Ghosh et al. (2010) reported that there were significant increases in nutrient availability with the application of farm yard manure ( $\left.7.5 \mathrm{t} \cdot \mathrm{ha}^{-1}\right)$, paddy straw (10 t. $\left.\mathrm{ha}^{-1}\right)$ and green manure $\left(8 \mathrm{t} \cdot \mathrm{ha}^{-1}\right)$ along with inorganic fertilizer. Organic materials (compost) in combination with chemical fertilizer increased the biomass and grain yields of crops (Sarwar et al., 2007; Sarwar et al., 2008). Similar results were obtained by other researchers (Parmer \& Sharma, 2002; Cheuk et al., 2003). 


\subsection{Water use efficiency}

Organic matter in soil improves soil structure, nutrient retention, water infiltration and water holding capacity (Deksissa et al., 2008). According to Brady \& Weil (2005), organic matter can improve the physical properties of the soil and cause increased root development which helps the uptake of more water and nutrients. Conservation agricultural practices such as maintaining the crop residues on the soil surface can play an important role in sustaining soil fertility, improving water use efficiency, physical conditions of soils and enhancing crop productivity (Kabir, 1999; Dalal \& Chan, 2001; Lampurlanes et al., 2001; Mohammad et al., 2003).

Improvement in WUE by using organic fertilizers is due to improvements in soil structure and its water retention capacity (Bhagat \& Verma, 1991), increases in water infiltration rates (Acharya et al., 1988) and a reduction in bulk density. Positive effects of organic waste materials on soil structure, aggregate stability and water holding capacity have been reported previously in several studies (Wells et al., 2000; Odlare et al., 2008). Gregorich et al. (1997) indicated that sludge organic matter and organic composts enhanced soil water retention and plant available water through increasing water absorption capacity. Application of MSW is commonly applied to soils to improve their physical, chemical and biological properties. Studies show that MSW can be useful in crop production (Ahmad et al., 1998; Cherif et al., 2009). Filter cake application to crops improved its soil physical properties such as stability and average weighted diameter of aggregates (Vasconcelos et al., 2010) and can increase soil organic matter content (Elsayed et al., 2008).

Sushila \& Gajendra (2000) and Camara et al. (2003) reported that the combined application of FYM and $\mathrm{N}$ fertilizer increased the growth, yield and water use efficiency of wheat under water-limited conditions. The results obtained are in line with Hati et al. (2006) who reported that application of organic waste $\left(10 \mathrm{t} \cdot \mathrm{ha}^{-1}\right.$ FYM) and the recommended dose of NPK to soybean for three consecutive years improved grain yield and water use efficiency by $103 \%$ and $76 \%$ respectively over the control. In addition, it also improved the saturated hydraulic conductivity, root length density and lowered soil bulk density.

\subsection{Soil carbon sequestration}

Soil organic carbon is an important indicator of soil quality and agriculture sustainability as it affects soil physical, biological and chemical properties (Reeves, 1997). Fertilizer addition on a regular basis leads to an increase in soil organic carbon, soil microbial biomass and also changes soil carbon and nitrogen dynamics
(Smith et al., 1994). Organic amendments influence soil characteristics by modifying its biological, chemical and physical properties (Van-Camp et al., 2004).

The results obtained indicated that application of organic amendments alone and integrated with chemical NPK fertilizers increased the TOC in surface soil. Likely a significant increase was also observed in grain and straw yield of wheat in these treatments. There may also be increase in root yield although we did not record the root data. After harvest, some part of straw and whole root remained in soil.

The possible reasons for increasing soil organic carbon by application of organic materials might be due to increased crop yield and better root growth under these treatments as well as the $\mathrm{C}$ contained in the wastes themselves. Benbi et al. (1998) found that farm yard manure in combination with NPK chemical fertilizers resulted in higher soil organic carbon concentration, enhanced crop growth along with higher root biomass production. Similarly, Zhao et al. (2009) found that soils amended with organic fertilizers improved the organic matter content.

The climatic and soil conditions of cultivated soil of Pakistan are favourable for rapid decomposition and mineralization. Due to favourable soil conditions and temperature, the particulate organic matter is rapidly decomposed to pool of total OM and that may be one of the reasons for increase of total OC. Mohammad et al. (2012) also observed an increase in soil TOC due to addition of crop residues. However, this increase in soil TOC is usually decreased after 2-3 weeks as our soil and climatic conditions are favourable for rapid decomposition and mineralization. Therefore we have used maize residues (wide $\mathrm{C}: \mathrm{N}$ ratio material) to lower the decomposition and mineralization process for reducing the $\mathrm{C}$ and nutrients loses during fallow period between two crops.

The organic wastes (filter cake and MSW) sole application resulted $40 \%$ and $38 \%$ increase in dry matter yield over control, respectively. The higher dry matter yield under filter cake and MSW treatments may also have greater root yield as compared to control treatment that contributed to soil higher organic carbon content. According to Yadav et al. (1998), soil organic carbon was increased by the continuous application of different combinations of $\mathrm{N}, \mathrm{P}$ and $\mathrm{K}$, whereas it decreased in unfertilized soils.

Integrated use of organic wastes and chemical fertilizers is effective in improving soil organic carbon and available N, P and K (Rautaray et al., 2003). According to Iqbal et al. (2012), the results obtained from field experiment conducted at Research Farm of University of Agriculture, Faisalabad, Pakistan revealed that application of dairy manure and nitrogen significantly increased soil organic carbon contents over control. Maximum value of organic 
carbon content $(0.78 \%)$ was observed with combined application of dairy manure $\left(50 \mathrm{Mg} \cdot \mathrm{ha}^{-1}\right)$ and $\mathrm{N}$ $\left(300 \mathrm{~kg} \cdot \mathrm{ha}^{-1}\right)$ at $0-5 \mathrm{~cm}$ depth during second year under maize cultivation.

\section{CONCLUSIONS}

Application of filter cake (sugar industrial waste) and municipal solid waste integrated with recommended NPK mineral fertilizers produced maximum wheat grain yield, WUE and improved TOC in surface soil $(0-15 \mathrm{~cm})$. It is recommended that both municipal solid waste and filter cake at $3 \mathrm{t} \mathrm{C} \cdot \mathrm{ha}^{-1}$ with recommended NPK fertilizers should be applied in wheat-maize cropping sequence in irrigated area of Khyber Pakhtunkhawa for obtaining higher crop productivity, water use efficiency and improving soil carbon status.

\section{List of abbreviations}

FC: Filter Cake

FYM: Farm Yard Manure

MR: Maize Residues

MSW: Municipal Solid Waste

SOC: Soil Organic Carbon

SOM: Soil Organic Matter

TOC: Total Organic Carbon

WUE: Water Use Efficiency

\section{Acknowledgements}

Financial support from the Higher Education Commission, Pakistan for conducting this research study is greatly acknowledged.

\section{Bibliography}

Abedi T., Alemzadeh A. \& Kazemeini S.A., 2010. Effect of organic and inorganic fertilizers on grain yield and protein building pattern of wheat. Aust. J. Crop Sci., 4(6), 384-389.

Acharya C.L., Bisnoi S.K. \& Yaduvanshi H.S., 1988. Effect of long-term application of fertilizers and organic and inorganic amendments under continuous cropping on soil physical and chemical properties in an Alfisol. Indian J. Agric. Sci., 58, 509-516.

Ahmad N., Rashid M. \& Vaes A.G., 1996. Fertilizers and their uses in Pakistan. Islamabad: National Fertilizer Development Centre.

Ahmad N. et al., 1998. Disposal of municipal waste on agricultural lands, its impact on soil environments, yields and quality of maize fodder and wheat grain. Pak. J. Soil Sci., 15, 47-51.

Ahmad R. et al., 2007. Bio-conversion of organic wastes for their recycling in agriculture. An overview of perspectives and prospects. Ann. Microbiol., 57, 471479.

Benbi D.K., Biswas C.R., Bawa S.S. \& Kumar K., 1998. Influence of farmyard manure, inorganic fertilizer and weed control practices on some soil physical properties in a long-term experiment. Soil Use Manage., 14, 52-54.

Bhagat R.M. \& Verma T.S., 1991. Impact of rice straw management on soil physical properties and wheat yield. Soil Sci., 152, 108-115.

Black C.A., ed., 1965. Methods of soil analysis. Part II. Madison, WI, USA: American Society of Agronomy Inc.

Bolan N.S. et al., 2004. Gaseous emissions of nitrogen from grazed pastures: processes, measurements and modelling, environmental implications and mitigation. Adv. Agron., 84, 37-120.

Brady N.C. \& Weil R.R., 2005. The nature and properties of soil. $13^{\text {th }}$ ed. New York, NY, USA: MacMillan Publishing Co.

Bremner J.M. \& Mulvaney C.S., 1982. Nitrogen-total. In: Page A.L., Miller R.H. \& Keeney D.R., eds. Methods of soil analysis. Part II. $2^{\text {nd }}$ ed. Madison, WI, USA: American Society of Agronomy Inc., 595-624.

Camara K.M., Payne W.A. \& Rasmussen R.A., 2003. Long term effect of tillage, nitrogen and rainfall on winter wheat yield in the Pacific Northwest. Agron. J., 95, 828835.

Cherif H. et al., 2009. Effects of municipal solid waste compost, farmyard manure and chemical fertilizers on wheat growth, soil composition and soil bacterial characteristics under Tunisian arid climate. Eur. J. Soil Biol., 45, 138-145.

Cheuk W., Lo K.V., Branion R.M.R. \& Fraser B., 2003. Benefits of sustainable waste management in the vegetable greenhouse industry. J. Environ. Sci. Health, 38, 855-863.

Dalal R.C. \& Chan K.Y., 2001. Soil organic matter in rainfed cropping systems of the Australian cereal belt. Aust. J. Soil Res., 39, 435-464.

Deksissa T., Short I. \& Allen J., 2008. Effect of soil amendment with compost on growth and water use efficiency of Amaranth. In: Proceedings of the UCOWR/ NIWR Annual Conference, International Water Research Challenges for the $21^{\text {st }}$ Century and Water Resources Education, July 22-24, 2008, Durham, NC, USA.

Diacono M. \& Montemurro F., 2010. Long-term effects of organic amendments on soil fertility. A review. Agron. Sustainable Dev., 30(2), 401-422.

Elsayed M.T. et al., 2008. Impact of filter mud applications on the germination of sugarcane and small-seeded plants and on soil and sugarcane nitrogen contents. Bioresour. Technol., 99(10), 4164-4168.

Ghosh S. et al., 2010. Management of soil quality and carbon sequestration with long-term application of organic amendments. In: Proceedings of $19^{\text {th }}$ World Congress of Soil Science, Soil Solutions for a Changing World, August, 1-6, 2010, Brisbane, Australia, 146-149. 
Gitari J.N. \& Friesen D.K., 2001. The use of organic/ inorganic soil amendments for enhanced maize production in the central highlands of Kenya. In: Seventh Eastern and Southern Africa Regional Maize Conference, February, 5-11, 2002, Nairobi, Kenya. Nairobi: KARI/CIMMYT, 367-371.

Goyal S., Chander K., Mundra M.C. \& Kapoor K.K., 1999. Influence of inorganic fertilizers and organic amendments on soil organic matter and soil microbial properties under tropical conditions. Biol. Fertil. Soils, 29, 196-200.

Gregorich E.G. et al., 1997. Biological attributes of the quality. In: Gregorich E.G. \& Carter M.R., eds. Soil quality for crop production and ecosystem health. Amsterdam, The Netherlands: Elsevier, 81-113.

Hati K.M. et al., 2006. Effect of inorganic fertilizer and farmyard manure on soil physical properties, root distribution, and water use efficiency of soybean in vertisols of central India. Bioresour. Technol., 97(16), 2182-2188.

Heanes D.L., 1984. Determination of total organic - C in soils by an improved chromic acid digestion and spectrophotometric procedure. Commun. Soil Sci. Plant Anal., 15, 1191-1213.

Hussain T., 2001. Manures and organic wastes. In: Soil Science. $2^{\text {nd }}$ ed. Islamabad: National Book Foundation, 387-403.

Hussain T. et al., 1999. Rice and wheat production in Pakistan with effective microorganisms. Am. J. Altern. Agric., 1, 30-36.

Iqbal M.M., Shah S.M., Hussain S.K. \& Saddiqui S.H., 1995. Crop nitrogen recovery and soil nitrogen residues from $15 \mathrm{~N}$-labelled urea applied to wheat. In: Proceedings of a FAO/IAEA regional seminar, Nuclear methods in soil plant aspects of sustainable agriculture, April, 5-9, 1993, Colombo, Sri Lanka, IAEA-TECDOC-785, 43-49.

Iqbal M.M. et al., 2012. Soil organic carbon, nitrate contents, physical properties and maize growth as influenced by dairy manure and nitrogen rates. Int. J. Agric. Biol., 14, 20-28.

Jilani G. et al., 2007. Enhancing crop growth, nutrients availability, economics and beneficial rhizosphere microflora through organic and biofertilizers. Ann. Microbiol., 57, 177-183.

Kabir A., 1999. Fertilizing with organic wastes to improve physical characteristics of soils. The Daily News International, April, 26 ${ }^{\text {th }}, 1999$.

Khoshgoftarmanesh A.H. et al., 2010. Micronutrientefficient genotypes for crop yield and nutritional quality in sustainable agriculture. A review. Agron. Sustainable Dev., 30, 83-107.

Kirda C., 1990. Use of neutron water and gamma density gauges in soil water studies. In: Use of nuclear techniques in studies of soil-plant relationships. Vienna: IAEA, 183-223.

Lal R., 2004. Soil carbon sequestration to mitigate climate change. Geoderma, 123, 1-22.
Lal R., 2006. Enhancing crop yields in the developing countries through restoration of the soil organic carbon pool in agricultural lands. Land Degrad. Dev., 17, $197-$ 209.

Lal R., Kimble J.M. \& Follett R.F., eds, 1999. Recommendations and conclusions. In: Agricultural practices and policies for carbon sequestration in soil. An international symposium, July 1999, Ohio State University, Columbus, USA. Boca Raton, FL, USA: Lewis Publishers.

Lampurlanes J., Angas P. \& Cantero-Martinez C., 2001. Root growth, soil water content and yield of barley under different tillage systems on two soils in semiarid conditions. Field Crops Res., 69, 27-40.

Mian S.M., Hassan M.M. \& Salim M., 1990. Relative effect of organic manures and chemical fertilizers on ion uptake and growth of wheat. In: Proceedings of the $2^{\text {nd }}$ national congress of soil science, December, 20-22, 1990, Faisalabad, Pakistan, 65-68.

MINFAL, 2012. Agricultural Statistics of Pakistan. Islamabad: Government of Pakistan, Ministry of Food, Agriculture and Livestock (Economic wing).

Mohammad W., Shah Z., Shah S.M. \& Iqbal M.M., 2003. Wheat yield, fertilizer $\mathrm{N}$ utilization and water use efficiency as influenced by tillage and $\mathrm{P}$ levels under rainfed conditions. Pak. J. Soil Sci., 22(1), 11-18.

Mohammad W., Shah Z., Shah S.M. \& Shehzadi S., 2008. Response of irrigated and N-fertilized wheat to legumecereal and cereal-cereal rotation. Soil Environ., 27(2), 148-154.

Mohammad W., Shah S.M., Shehzadi S. \& Shah S.A., 2012. Effect of tillage, rotation and crop residues on wheat crop productivity, fertilizer nitrogen and water use efficiency and soil organic carbon status in dry area (rainfed) of north-west Pakistan. J. Soil Sci. Plant Nutr., 12(4), 715727.

Muhammad W., Vaughan S.M., Dalal R.C.\& Menzies N.W., 2011. Crop residues and fertilizer nitrogen influence residue decomposition and nitrous oxide emission from a Vertisol. Biol. Fertil. Soils, 47, 15-23.

Odlare M., Pell M. \& Svensson K., 2008. Changes in soil chemical and microbiological properties during 4 years of application of various organic residues. Waste Manage., 28, 1246-1253.

Pang X.P. \& Latey W., 2000. Organic farming challenge of timing and nitrogen availability to crop requirements. Soil Sci., 64, 246-253.

Parmer D.K. \& Sharma V., 2002. Studies on long term application of fertilizers and manure on yield of maize-wheat rotation and soil properties under rainfed conditions in Western-Himalayas. J. Indian Soc. Soil Sci., 50(3), 311-312.

Rashid A., 1994. Annual report of micronutrient project. Islamabad: Land Resources Research Institute, NARC.

Rashid A. \& Ahmad N., 1994. Soil testing in Pakistan. In: FADINAP Regional workshop on cooperation in soil 
testing of Asia and the Pacific, August, 16-18, 1993, Banghok, Thailand. New York, USA: United Nations, 39-53.

Rautaray S.K., Ghosh B.C. \& Mittra B.N., 2003. Effect of fly ash, organic wastes and chemical fertilizers on yield, nutrient uptake, heavy metal content and residual fertility in rice-mustard cropping sequence under acid lateritic soils. Bioresour. Technol., 90, 275-283.

Reeves D.W., 1997. The role of soil organic matter in maintaining soil quality in continuous cropping systems. Soil Till. Res., 43, 131-167.

Rengel Z., Batten G.G. \& Crowley D.E., 1999. Agronomic approaches for improving the micronutrient density in edible portions of field crops. Field Crops Res., 60, $27-$ 40 .

Roca-Perez L., Martinez C., Marcilla P. \& Boluda R., 2009. Composting rice straw with sewage sludge and compost effect on the soil-plant system. Chemosphere, 75(6), 781-787.

Sarwar G., Hussain N., Schmeisky H. \& Muhammad S., 2007. Use of compost an environment friendly technology for enhancing rice-wheat production in Pakistan. Pak. J. Bot., 39(5), 1553-1558.

Sarwar G. et al., 2008. Improvement of soil physical and chemical properties with compost application in ricewheat cropping system. Pak. J. Bot., 400, 275-282.

Schulin R. et al., 2009. Effect of soil management on zinc uptake and its bioavailability in plants. In: Banuelos G.S. \& Lin Z., eds. Development and uses of biofortified agricultural products. Boca Raton, FL, USA: CRC Press.

Shah Z. \& Anwar M., 2003. Assessment of municipal solid waste for nutrient elements and heavy toxic metals. Pak. J. Soil Sci., 22(4), 1-10.

Shah Z. et al., 2003. Crop residue and fertilizer $\mathrm{N}$ effects on nitrogen fixation and yields of legume-cereal rotations and soil organic fertility. Field Crops Res., 83, 1-11.
Shah Z. \& Ahmad M.I., 2006. The integrated effect of farm yard manure and urea on crop and nitrogen yields of wheat. J. Agric. Biol. Sci., 1(1), 60-64.

Smith C.J., Chalk P.M., Crawford D.M. \& Wood J.T., 1994. Estimating gross nitrogen mineralization and immobilization rates in anaerobic and aerobic soil suspensions. Soil Sci. Soc. Am. J., 58, 1652-1660.

Soltanpour P.N. \& Schwab A.P., 1977. A new soil test for simultaneous extraction of micro and macro nutrients in alkaline soil. Commun. Soil Sci. Plant Anal., 9, 195-207.

Sushila R.\& Gajendra G.I.R.I., 2000. Influence of farmyard manure, nitrogen and biofertilizers on growth yield attributes and yields of wheat under limited water supply. Indian J. Agron., 45, 590-595.

Van-Camp L. et al., 2004. Reports of the technical working groups established under the thematic strategy for soil protection. EUR21319 EN/3. Luxembourg: Office for Official Publications of the European Communities.

Vasconcelos R.F.B., 2010. Limites de consistência e propriedades químicas de um Latossolo Amarelo distrocoeso sob aplicação de diferentes resíduos da canade-açúcar. Rev. Bras. Ciênc. Solo, 34(3), 639-648.

Wells A., Chan K. \& Cornish P., 2000. Comparison of conventional and alternative vegetable farming systems on the properties of a yellow earth in New South Wales. Agric. Ecosyst. Environ., 80, 47-60.

Yadav R.L., Yadav D.S., Singh R.M. \& Kumar A., 1998. Long-term effects of inorganic fertilizer inputs on crop productivity in a rice-wheat cropping system. Nutr. Cycling Agroecosyst., 51, 193-200.

Zhao Y. et al., 2009. The effects of two organic manures on soil properties and crop yields on a temperate calcareous soil under a wheat-maize cropping system. Eur. J. Agron., 31, 36-42.

(65 ref.) 